\title{
Philosophy as de-anthropologized knowledge: a contribution of Russian empiriocriticism
}

\author{
A. E. Rybas \\ St. Petersburg State University, \\ 7-9, Universitetskaya nab., St. Petersburg, 199034, Russian Federation
}

For citation: Rybas A.E. Philosophy as de-anthropologized knowledge: a contribution of Russian empiriocriticism. Vestnik of Saint Petersburg University. Philosophy and Conflict Studies, 2019, vol. 35, issue 1, pp. 107-118. https://doi.org/10.21638/spbu17.2019.109

\begin{abstract}
The article provides an analysis of the "problem" approach to understanding a human being. This approach was a characteristic feature of the followers of empiriocriticism in Russia at the turn of the $20^{\text {th }}$ century. It is shown that this approach suggests the possibility of a procedural understanding of the objectness of philosophical knowledge which in turn requires the metaphysical rationality to be critically overcome. Russian positivism is discussed by means of analyzing the two main "irritants" of the philosophical tradition: antimetaphysical pathos and a new model of knowledge. Metaphysics, as an object of criticism of the Russian positivists, was considered to be a special strategy of comprehending absolute truth, or such a system of knowledge that was based on ignorance, that is, on a whole series of assumptions accepted on faith and never verified. It is shown that the criticism of metaphysics led the empiriocritics to develop their own alternative projects to prove the possibility of monistic philosophy. The most interesting experiments of constructing a system of "non-metaphysical all-unity" were the theories of empiriomonism and tektology of Aleksandr Bogdanov, scientific philosophy of Vladimir Lesevich, empiriosymbolism of Pavel Yushkevich, philosophy of life of Sergey Suvorov, as well as positive aesthetics of Aleksandr Lunacharsky. These theories are considered in the context of modelling a system of new, non-classical, or de-anthropologized, philosophical knowledge. The problem of man is described by means of both destruction and actualization of its main historical interpretations. The thesis of the Russian positivists that philosophy can exist only in the form of a historico-philosophical discourse which is held to create a possible reality rather than to reconstruct the existing philosophical doctrines is corroborated.
\end{abstract}

Keywords: Russian philosophy, empiriocriticism, positivism, problem of man, subject, destruction of subjectivity, constructing a man, de-anthropologized knowledge.

The crisis of classical rationality, which became inevitable at the turn of the $19^{\text {th }}$ and $20^{\text {th }}$ centuries, radically changed the understanding of the object field and methods of philosophical cognition [1]. First of all, it became obvious that metaphysics "had come to an end", and even those philosophers who tried to defend metaphysics against the attacks of "critical thinking" in order to restore it as a "strict science" were compelled to consider this fact [2]. In addition, the task of philosophical cognition was more and more often believed to be a creative modelling of possible reality rather than grasping the invariant universal truth corresponding to the genuine reality [3]. Thus, in the early $20^{\text {th }}$-century philosophy there appeared two main tendencies which determined the specificity of philosophical research, namely: the construction of non-metaphysical philosophy, and the justification of philosophy as problem knowledge.

(C) Санкт-Петербургский государственный университет, 2019 
In Russian philosophy of the $20^{\text {th }}$ century, these tendencies were also decisive, despite the fact that they are often ignored, especially when historians try to reduce the complex process of development of the philosophical culture in Russia to one or another dominating tradition, whether it be religious or Marxist. In this regard, it is of interest to point out a coincidence, which is very significant and by no means accidental, between the views of the supporters of both religious and Marxist interpretations of Russian philosophy. This coincidence can be seen in the irreverent attitude to the position of Russian positivism. Indeed, both religious and Marxist historians of Russian philosophy claim that positivism, in spite of its being popular among the Russian philosophizing intellectuals of the Silver Age, cannot be considered as real philosophy and, therefore, as a tradition belonging to the philosophical culture of Russia [4]. Obviously, the main reason for this negative attitude toward Russian positivism should be explained by the fact that the positivist thinkers tried to change the very essence of philosophical discourse. This resulted in discrediting the "eternal" questions of philosophy, on the one hand, and in treating philosophy as an art of life rather than cognition of the objective reality, on the other [5].

To begin with, let us consider Russian positivism by means of analyzing the two main "irritants" of the philosophical tradition: antimetaphysical pathos and a new model of knowledge. Then the idea of de-anthropologized knowledge, one of the central in empiriocriticism in its Russian version, will become clear.

\section{Criticism of the metaphysical rationality}

Metaphysics, as an object of criticism of the Russian positivists, is a special strategy of comprehending absolute truth. Historically, the notion of absolute truth, like the ways of its objectification, can change, but the belief of philosophers that they do have an "access to reality" remains unchanged, which turns the philosophers into metaphysicians. It is necessary, therefore, to analyze the possibility of this access, or, what is the same, to explore the "metaphysical feeling" - the sixth sense of the thinking person. This is what the Russian positivists do, first of all, showing in the end that the "secret" of metaphysics is simple: it consists in dualism.

Dualism is a convenient means of presenting things, a well-known way of explaining what is given in experience by appealing to what is beyond any experience; as a result of it, things in existence are interpreted as being related to their a priori essences. The dualistic explanation of what exists, if we consider it as a mechanism for producing objectivity, boils down to the following: the actual and meaningful content of experience (what we are dealing with here and now, which is important for our life) is endowed with an attribute of truth (or lie) by means of the instance of Truth, which is claimed to be ever beyond experience and, therefore, which can never be actualized because it intrinsically differs from those things that are subject to knowledge. It turns out that the foundation of our knowledge always lies in ignorance, and this ignorance is a sine qua non-condition for any cognition. Strange as it may seem, the possibility and development of our knowledge depend directly on the assumption that we know that there is unknowable. The unknowable world of "things-in-themselves", thus, enables the cognizability of "things-for-us", and its unknowability is something quite obvious, understandable and necessary.

Dualism, as a method of metaphysical cognition, necessarily requires the ontologization of the cognized and the unknowable, as a result of which the content of knowledge 
and its condition are considered as isolated from the process of cognition. According to the Russian positivists, the main drawback of dualism, namely the inevitability of dividing things into two essentially different parts that do not overlap, leads to a number of negative consequences: for example, the world breaks up into the realm of ideas and the system of things, man is believed to consist of a soul and a body, natural sciences are opposed to the humanities. Metaphysics, based on a dualistic interpretation of what exists, also implies the ontologization of this interpretation, and the order of ideas is declared to be identical with the order of things: the way we perceive things determines what they really are, therefore, the external world is cognized only through its ideal representation in thought. As a result, the being of things is interpreted through thinking, that is, through its rational transcription, or rather, abstraction.

Thus, metaphysics described by the Russian positivists is such a system of knowledge that is based on ignorance, that is, on a whole series of assumptions which have been accepted on faith and are never verifiable, and these assumptions, being hypothetical, are groundlessly claimed to be apodictic. In this respect, metaphysical thinking is rather simplistic, as it exclusively deals with itself. Moreover, the inability to cognize what really exists is characterized by metaphysicians as their "access to reality". It is no wonder that there appeared a fictitious picture of the world - the result of metaphysical work, logically consistent but with no cognitive value.

Metaphysical rationality, as Vladimir Lesevich put it, does not have any grounds in reality and does not know the limits of its activity. Metaphysics should be regarded as referring to poetic creativity rather than to philosophy, since "only poetic works are written to express one idea and are created by one person" [6, p. 239]. Metaphysical systems must be treated, therefore, as works of art, which can make our life more interesting but fail to help us cognize it. It is, of course, no accident that the language used by metaphysicians to describe their doctrines abounds in literary devices such as allegories and metaphors. Indeed, metaphors and allegories are appropriate only in the case where the author tries to express his unique, subjective experience rather than objective reality. "Subjective speculation constructs a lot of bold, complicated, harmonious and majestic systems in which even the most contradictory facts become consistent with the basic principle" [7, p.59]. The creative work of a metaphysician goes on as follows: "the abstract concepts are stealthily objectified, the words are taken for the very objects and, thus, there appears a whole series of realized abstractions, such as essence, ultimate goal, first cause, etc." [7, p. 59].

According to Aleksandr Bogdanov, metaphysical rationality can hardly be philosophical; rather, it should be characterized as vulgar because the metaphysician dealing with solving "ultimate" questions cannot go without the commonplace distinction between the "higher" and the "lower", etc. It is obvious that the very "concept of the 'absolute' is completely fictitious, because the content of concepts is taken only from experience, and in experience there is not and cannot be anything absolute" [8, p. 153]. The truths which are really cognized and which to determine the existence of man cannot be absolute: they are "living organizing forms of experience", therefore they should not only be "discovered" or "grasped", they should rather be a guideline in human activity, "lead" people, provide them "a fulcrum in the life struggle" [9, p.219]. The vital meaning of truth is not determined by the fact that it is eternal or unchanging, it is determined by the fact that truth can be a goal for joint action and at the same time an instrument for achieving this goal. And just as 
the last goal would signify the end of the movement, and hence the end of life, so the last, absolute truth would signify the end of thinking, creative activity of man $[10 ; 11]$.

From the point of view of Pavel Yushkevich, metaphysics is a natural product of "substantial thinking". This kind of thinking is characterized primarily by the fact that it is based on faith in the substance - the "artistic symbol" created by the primitive man for the purpose of systematizing a rather limited range of phenomena, namely his experiments with solids. Thus, "substantialism is, primarily, the ideology of solids, the ideology of tactile perceptions developed into the Absolute" [12, p. 145], and the limits of its applicability are determined by the degree of primitiveness of human experience. So, for everyday life, the metaphysics of substantialism is quite suitable, since it represents what exists in its finite definiteness, and the world as a whole - as a logically ordered system of things or a picture. Due to the metaphysics of substantialism man acquires that "simplicity of view" which enables him to see something eternal, "genuine" in the ever-changing and diverse world. However, for philosophical reflection, metaphysical thinking is unacceptable because it focuses exclusively on grasping the "genuine" and therefore loses sight of the actual content of experience. Pavel Yushkevich contrasted metaphysical substantialism with philosophical "constantism" which he considered such an approach to the interpretation of what exists that would make it possible to create an appropriate picture of the world in its dynamics. That is, this world picture should reflect, on the one hand, the ontological unity of being, and on the other, the relativity and infinity of its cognition.

\section{The project of problem knowledge}

Practically all those philosophers in Russia who accepted empiriocriticism and criticized the dualistic metaphysics for its being unable to contribute to philosophical cognition developed alternative projects and tried to prove the possibility of monistic philosophy. The most interesting experiments of constructing a system of "non-metaphysical allunity" were the theories of empiriomonism and tektology of Aleksandr Bogdanov [9;13], scientific philosophy of Vladimir Lesevich [6], empiriosymbolism of Pavel Yushkevich [12], philosophy of life of Sergey Suvorov [14], as well as positive aesthetics of Aleksandr Lunacharsky [15]. These theories, despite their having much in common, including the basic assumptions and principal conclusions, were quite diverse. However, each of them was an attempt at modelling a system of new, non-classical knowledge. If we summarize the ideas expressed by the Russian positivists in this respect, we can see that all of them considered philosophical knowledge as a "problem" one.

Describing philosophy as a "problem" knowledge, it is first of all necessary to pay attention to the specificity of the concept "problem". It is well known that in formal logic the problem is defined as the situation determined by the two factors: 1) the question raised for inquiry or solution cannot be answered or solved; 2) this question should be solved at all costs. Consequently, the problematic situation implies the urgency of the question posed, on the one hand, and the inability to find the appropriate answer, on the other. In philosophy, the problem is also understood as the lack of a solution; however, this lack is not be regarded as a shortcoming of philosophical knowledge. Quite the contrary, it is due to the inability to find the appropriate answer to the question that this question becomes philosophical. This means that the problem posed for inquiry is valuable as itself and does 
not involve the search for final solutions; moreover, the very idea of such solutions prevents from any philosophical investigation.

The "problem" character of philosophy, as the Russian positivists understood it, first of all implies the refusal to aim at absolute knowledge. They believed that "the age of world picture" had passed as it became obvious long ago that the world we live in and try to cognize is not equivalent to what exists and is called reality, no matter as reality is considered: empirically - as a set of phenomena existing here and now; transcendentally — as the realization of a priori forms of cognition; metaphysically — as a system of eternal ideas or essences. A fundamental characteristic of reality is that it is a process, therefore, the reality is principally uncompleted and open for creative activity of man. Philosophical cognition of reality became a matter of great difficulty as soon as philosophers had realized that the world is ever changeable, not stable. Obviously, in order to grasp the changeable, it is necessary to proceed from the primacy of what will possibly be over what does exist now. It is what will possibly be but does not exist now that determines the essence of what really is; thus, reality is always projective, it is interpreted from the point of view of the future, for only in this case reality can be rationally systematized to be appropriate for man to live as a human being.

Having taken into consideration the projective character of philosophical cognition, the Russian positivists called for a greater focus on the very questions, or problems, rather than their solutions. In their opinion, a philosophical inquiry should begin with posing questions correctly so that they will stay actual and conscious. Neither the Absolute nor eternal essences should be the subject matter of philosophy. Accordingly, philosophers should cease to explain the world or justify the existing cultural, religious, aesthetic and other values by means of constructing metaphysical doctrines. What they are able and ought to do is to propose and substantiate various projects of reality.

\section{Man as a problem of philosophy}

The "overcoming" of metaphysics and the understanding of philosophy as "problem" knowledge made it possible to ground a new perspective for interpreting the concept of "man", which is fundamental to the world outlook of classical rationalism [16]. Man has become a problem: this means that, firstly, the anthropocentric principle of interpreting what exists has ceased to be the determining factor of philosophical thinking, since man and the subject of cognition has been distinguished; secondly, man has "lost" the ontological grounds enabling him to notice "the genuine in himself", for example such essential characteristics as "universality", "ahistoricity", "autonomy", "self-sufficiency", "unconditional value"; thirdly, man has realized his "derivativeness" and "finiteness", he has learned to look at himself "from the outside" and got an opportunity for a projective, or creative, existence.

Man taken as a problem of philosophy points primarily to the fact that the model of subjectivity formed in the classical rationalistic philosophy has failed to play its role as a pillar of philosophical cognition and guarantor of true judgments concerning things; moreover, this model which is still being used by philosophers represents an obstacle to philosophical thinking [17]. According to the Russian positivists, such Cartesian model of man as res cogitans, corresponding to the requirements of the scientific discourse of the classical era, makes it very difficult to understand the key moments of reality and, 
therefore, should be discarded. However, the destruction of the Cartesian subjectivity and the critical analysis of the discourse that gave rise to the corresponding interpretation of man is just a preliminary, albeit necessary, condition for positive philosophy. The main task of criticism of the historically formed ideas about man consists in the justification of the need for an "empty", or de-anthropologized, space for philosophical thought development. In other words, the task of criticizing the classical subjectivity is to undermine the persuasiveness of the traditional interpretations of man in order to prove the relativity, or conventionality, of any, including positivistic, subject theories.

Obviously, if the task of criticism was only to show the falsity of the model of man elaborated in the paradigm of classical rationalism, it would be possible to hope that the essence of man may be discovered and represented correctly sometime in the future. In this case, the Cartesian subject theory would be criticized as only a hindrance to the proper perception of what exists as if it was possible to break the laws of "anthropological sleep"; the classical model of man would be identified with a distorting "mirror of nature", etc. Therefore, it would seem conceivable that after the hindrance was removed, the philosopher could find an appropriate approach to grasping the true essence of man, on the one hand, and the genuine reality, on the other. However, the Russian positivists insisted that there is an irremovable obstacle to philosophical cognition - that one which should be taken into account when constructing a world picture. This obstacle is the man himself, that is, the actual subject theory which precedes and determines any philosophical investigation. Since it is impracticable to avoid it, the philosopher should proceed from the assumption that the subject theory he adheres to is really valid for cognition and at the same time it is merely a creative fiction which is necessary to be exposed as a false statement. Such an acceptance- rejection of the subject theory will help consider reality as a process, in its dynamics.

\section{The "death" of man}

Describing the "empty", or de-anthropologized space as a sine qua non-condition for philosophical reflection, the Russian positivists relied upon the thesis of the "death" of man - one of the central statement, which each of them tried to develop in their own way. They argued that in order to correctly raise the question what man is one should proceed from the fact of the finiteness of man. Here we can see the influence of F. Nietzsche, whose well-known aphorism "God is dead" pronounced by a "mad man" [18, p. 593] provoked a number of fruitful discussions among the Russian positivists who developed this statement and proposed their own ideas (in particular, the thesis of the "death" of God became the theoretical basis for the doctrine of God-Building, and the thesis of the "death" of man was interpreted to ground the concept of a "new" personality) [19, p. 170-179]. In addition, the criticism of the moral interpretation of the world and man, initiated by F. Nietzsche, enabled the Russian positivists to overcome the traditional philosophical view that the essence (nature) of a thing is more fundamental and immutable than its existence (the mere fact of its being). As a result, they came to the conclusion that existence precedes essence and is, therefore, more essential. Thus, what is called and really is "man" is determined by random existential factors, such as, for example, various "perspectives" dealt with the realization of the "will to power", the confrontation between different "interests" or "needs", etc. It is due to the fact that it is impossible to anticipate every contingency that these factors can be re- 
garded as necessary; in this respect, contingency plays here a key role, so it can be identified with the cause of necessity. Indeed, only what has happened to exist necessarily is because it happened to be this way and not otherwise; what has happened, or become, is irreversible and therefore necessary. Moreover, what has happened to exist is always unique. As something unique, it is finite, on the one hand, and ineffable, on the other.

Man as something which came into being by chance and therefore necessarily exists as a unique creature is known to be capable of self-reflection. Due to this ability, a man reveals himself as a problem as soon as he renounces the traditional habit of "thinking only in the form of speech" [20, p.296], that is, of determining what exists including his own being by appealing to a priori essences or ideas. Man is considered a problem because when describing himself as "the being of becoming" he has to somehow define himself, and each time when he does it, he thereby distinguishes himself from what has been grasped in the self-definition, demonstrating the impossibility of any appropriate definition whatsoever. A man reflecting upon his own essence, therefore, is not fundamentally what he is. He "dies" as soon as he declares his "being".

The thesis of the death of man leads to the idea that man turns out to be somebody else - the other one who essentially differs from what has been defined as his essence in the act of self-knowledge. It should be stressed that the variable "otherness" of the man like his invariant "being" cannot be properly defined either. Moreover, it can not be grasped from an outside perspective, because neither the "honoured interlocutor" [21] nor "the Other" [22] will guarantee the cognition of man as the other one. Thus, the image of the otherness is created each time anew by means of a number of random factors. The problem of man, therefore, proves to be both the problem of identity and the problem of otherness. As a result, man is considered as an existential variable, or as a function of the place he occupies.

When discussing the functional status of man, the Russian positivists, on the one hand, relied on the ideas of European philosophers, primarily F. Nietzsche and K. Marx [23]. The latter, for example, defined the essence of man as "the aggregate of all social relations" [24, p. 3]; this was interpreted to prove that the essence of man as determined by the social and historical conditions is part of the everlasting process of renovation, regeneration, transformation and metamorphosis. On the other hand, in Russia at the end of the $19^{\text {th }}$ century, there was a much philosophical debate on the problem of subjectivity which continued until the era of official Marxism-Leninism. These are some key positions to be mentioned: A. I. Vvedensky's works initiated intensive discussions on issues dealt with "the other's I" [25; 26]; M. M. Bakhtin paid attention to the dangerous gap between "the two worlds, absolutely unconnected and not permeable to each other: the world of culture and the world of life" [22, p.7] and tried to bridge this gap with the help of his "philosophy of action" implying the necessity to take into account the "unique singularity of the lived life" [22, p. 7]; finally, V. I. Vernadsky in his doctrine of biosphere and noösphere criticized the philosophical theories proceeding from the view on man as a self-sufficient creature which essentially differs from both natural phenomena and other living beings on the Earth; V.I. Vernadsky stressed the "functional dependence of man as a natural object, and humanity as a natural phenomenon, on the environment of their life and thought" [27, p. 13] and concluded that since man can not be correctly understood outside the context of his existence, he should be regarded as a function of the biosphere and studied together with its habitat. 


\section{De-anthropologized cognition}

The problem approach to understanding man involves a specific way of research. Obviously, as soon as philosophers agree that there are no essential characteristics of man, they have to renounce their attempts of systematic research. Therefore, instead of positive knowledge about man they will be only able to draw up some philosophical declarations. Indeed, it seems impossible to philosophically cognize man when his essence is constantly changing. A skeptical conclusion that man is beyond philosophical cognition is likely to be inevitable.

However, the Russian positivists did not make up such a conclusion as they believed that it was necessary to resist skepticism and agnosticism by all means. First of all, they insisted that the statement that philosophical cognition of man aimed at discovering his essence is obviously fictitious does not prove the falsity of cognition of any kind. The criticism of metaphysical approaches helps only to understand that man has no ahistorical essence, which would completely determine his existence. Therefore, it is man's existence, not his essence that should be cognized. That is, the analysis of the various forms of man's existence determined by historical, social, cultural and other factors will make it possible to conceive what man really is. This means, inter alia, that man is to be studied primarily on the basis of the past, or on the basis of the time-tested forms of his existence.

On the one hand, every concrete form of subjectivity is historically determined and can not therefore be considered an adequate manifestation of the essence of man. On the other hand, every concrete form of subjectivity due to the fact that it has already come into being is likely to shed light on what man is. In this respect, what happened to come into being can be regarded as a realized possibility to exist, therefore, we can cognize man in the perspective of this realized possibility. The more forms of man's existence are taken into consideration, the more we can know what man is regardless of these forms. Thus, objectifying the content of the concept "man" is a difficult but not insurmountable challenge. To put it another way, a philosophical investigation of man is kind of studying the "tracks" that he leaves in history rather than grasping his eternal essence. Philosophical research resembles telling by the tracks because we study what has already become real and, therefore, really refers to the essence of man. It is important, however, not to try to get a complete knowledge of what man is. Each track helps to cognize something essential about the man, and at the same time, it distorts his essence. For example, the Cartesian subjectivity, if taken as the adequate model of human being, is certainly an obstacle to philosophical knowledge, and therefore, it should be necessarily criticized so that we could correctly raise the question of man's essence. However, the same Cartesian subjectivity, if understood in the context of the corresponding interpretation of man's existence, enables us to understand something essential about the man, namely his ability to construct such a picture of the world in which man will be an autonomous transcendental subject.

To conclude, the philosophical knowledge of man is made up of the sum of all the concepts which were formulated in order to explain the corresponding images of the man that existed before. It is nothing more than a systematized collection of man's "tracks" in history or, as the Russian positivists put it, "constructing man" [28], the only possible "objective" knowledge of his "essence". Described as objective, this knowledge is not understood as made up of hard facts that come from consensus built over time. Following F. Nietzsche's thesis that there are no facts, only their interpretations [20, p.281], the Rus- 
sian positivists regarded the historically determined images of man as such data which can and should be interpreted in different ways. Moreover, they stressed that what is called a fact is actually a series of multiple interpretations. As dealt with the present, they refer to the existing self-description of man, make it clear what man is considered to be; as dealt with the past, they help to know for sure what man happened to be. For example, the Cartesian subject can be regarded, on the one hand, as an appropriate characteristic of the corresponding epoch and metaphysical views, on the other, as a product of the actual historical and philosophical discourse; both approaches to the Cartesian subject are equally entitled to exist.

Since the historical data can be understood in different ways depending on how and for what they are actualized in the present, the history turns out, the Russian positivists believed, to be fundamentally variable. Due to the variability of history, there can be seen a continuum of interpretations in a limited number of facts. When systematizing the images of the man, which were characteristic for the past eras, we construct man as if he had an ahistorical essence. Thus, if we are able to understand subjectivity the way it was supposedly understood in some remote era, or if we are able to describe the functional status of man determining the corresponding interpretation of what exists, then we are likely to know something essential in man as such. The adequacy of interpretation of historical data, as it follows from the above, is not to be taken into account: since this or that interpretation has appeared, then the subjectivity dealt with it has already become a fact.

Finally, since cognition of man is possible only on the basis of the forms of his existence in history, philosophy is considered only as a history of philosophy. It is no accident that the followers of positivism in Russia paid much attention to the interpretation of the historical and philosophical process, proving that their position had resulted from the logical development of all thinking humanity [29; 30]. Indeed, in case the problem approach to understanding knowledge is realized, the historical past becomes the material for multiple interpretations, and "constructing man" is taken as the aim of philosophical cognition. In this respect, the attempts to study man as he functioned before are attempts of interpreting the essence of man in the context of his possible existence in the future. Philosophy as such a history of philosophy which is aimed at constructing man is obviously de-anthropologized.

\section{References}

1. Steila, D. (2013), Nauka i revoliutsiia. Retseptsiia empiriokrititsizma v russkoi kul'ture (1877-1910) [Science and Revolution: A Reception of Empirio-criticism in the Russian Culture (1877-1910)], transl. from Italian by O. Popova, Akademicheskii Proekt Publ., Moscow, Russia.

2. Soboleva, M.E. (2018), “Kriticheskii pozitivizm' protiv 'novogo idealizma' v Rossii nachala XX veka” ["Critical positivism" versus "new idealism" in Russia at the beginning of $20^{\text {th }}$ century], Vestnik $S P b G U$, ser. Philosophy and Conflict Studies, vol. 34, iss. 1, pp. 46-56.

3. Gusev, S. S. (1995), "Paradoks pozitivizma" [The paradox of positivism], in Zamaleev, A. F. and Novikov, A.I. (eds), Russkii pozitivizm: V.V.Lesevich, P.S. Iushkevich, A.A.Bogdanov [Russian positivism: V. V.Lesevich, P. S. Yushkevich, A.A.Bogdanov], Nauka, St. Petersburg, Russia, pp. 5-14.

4. Mikhailova, E.E. and Belchevichen, S.P. (2012), Pozitivizm i marksizm v Rossii: Problema sotsiokul'turnogo razvitiia [Positivism and Marxism in Russia: The problem of socio-cultural development], Tver branch of the Moscow Institute of Humanities and Economics, Tver, Russia.

5. Korobkova, S. N. (2014), "Stsientizm kak forma filosofskoi refleksii" [Scientism as a form of philosophical reflection], in Antokhin, Iu. A., ed., Nauchnaia sessiia GUAP. Sbornik dokladov, posviashchennykh Vsemirnomu Dniu aviatsii i kosmonavtiki [Scientific session of the SUAI. Collection of reports dedicated to 
the World Day of Aviation and Cosmonautics], in 3 pt., pt. 1, St. Petersburg State University of Aerospace Instrumentation, St. Petersburg, Russia, pp. 70-73.

6. Lesevich, V. V. (2011), Chto takoe nauchnaia filosofiia? [What is scientific philosophy?], Direct-Media, Moscow, Russia.

7. Lesevich, V. V. (1995), "Pervye provozvestniki pozitivizma” [The first heralds of positivism], in Zamaleev, A. F. and Novikov, A.I., eds, Russkii pozitivizm: V. V.Lesevich, P. S. Iushkevich, A. A. Bogdanov [Russian positivism: V. V. Lesevich, P. S. Yushkevich, A. A. Bogdanov], Nauka, St. Petersburg, Russia, pp. 55-106.

8. Bogdanov, A. A. (2010), Padenie velikogo fetishizma: Sovremennyi krizis ideologii [The fall of the great fetishism: The current crisis of ideology], Krasand, Moscow, Russia.

9. Bogdanov, A.A. (2003), Empiriomonizm: Stat'i po filosofii [Empiriomonism: Philosophy articles], Respublika, Moscow, Russia.

10. Plaggenborg, S. (2008), "Alexander Bogdanov: Vom Marxismus zur Anthropologie", in Alexander Bogdanov. Theoretiker für das 20. Jahrhundert, Verlag Otto Sagner, München, Germany, pp. 179-197.

11. Soboleva, M. (2007), A. Bogdanov und der philosophische Diskurs in Russland zu Beginn des 20. Jahrhunderts. Zur Geschichte des russischen Positivismus, Georg Olms Verlag, Hildesheim, Germany.

12. Yushkevich, P.S. (1995), "Sovremennaia energetika s tochki zreniia empiriosimvolizma" [Modern energetics in the terms of empiriosymbolism], in Zamaleev, A. F. and Novikov, A.I., eds, Russkii pozitivizm: V. V.Lesevich, P.S.Iushkevich, A.A.Bogdanov [Russian positivism: V.V.Lesevich, P.S. Yushkevich, A. A. Bogdanov], Nauka, St. Petersburg, Russia, pp. 107-164.

13. Bogdanov, A. A. (1989), Tektologiia: Vseobshchaia organizatsionnaia nauka [Tectology: General organizational science], Ekonomika Publ., Moscow, Russia.

14. Suvorov, S. (1905), "Osnovy filosofii zhizni" [Foundations of the philosophy of life], in Dorovatovskii, S. and Charushnikov, A., eds Ocherki realisticheskogo mirovozzreniia: Sbornik statei po filosofi, obshchestvennoi nauke $i$ zhizni [Essays on the realistic worldview: A collection of articles on philosophy, social science and life], $2^{\text {nd }}$ ed., Tipografiia Montvida, St. Petersburg, Russia, pp. 1-113.

15. Lunacharskii, A. V. (1905) "Osnovy pozitivnoi estetiki" [Foundations of positive aesthetics], in Dorovatovskii, S. and Charushnikov, A., eds Ocherki realisticheskogo mirovozzreniia: Sbornik statei po filosofii, obshchestvennoi nauke i zhizni [Essays on the realistic worldview: A collection of articles on philosophy, social science and life], $2^{\text {nd }}$ ed., Tipografiia Montvida, St. Petersburg, Russia, pp. 114-182.

16. Mikhailova, E.E. (2009), "Russkii pozitivizm na puti ponimaniia cheloveka, ego kul'tury i istorii" [Russian positivism on the way of understanding man, his culture and history], Filosofiia i kul'tura [Philosophy and culture], no. 7 (19), pp. 55-61.

17. Gusev, S. S., Efimov, Iu. I. and Mangasaryan, V. N. (2009), Problema cheloveka v filosofii i sovremennoi nauke [The problem of man in philosophy and modern science], Izdatel'stvo RHGA, St. Petersburg, Russia.

18. Nietzsche, F. (1990), "Veselaia nauka" [The merry science ('La gaya scienza')], in Nietzsche, F. Sochineniia [Works], in 2 vol., vol. 1, Mysl, Moscow, Russia, pp. 491-719.

19. Brodsky, A.I. and Rybas, A.E. (2013), Proekty Serebrianogo veka. Filosofskie idei russkogo moderna [Silver Age projects. Philosophical ideas of Russian art nouveau], Izdatel'stvo SPbGU, St. Petersburg, Russia.

20. Nietzsche, F. (2005), Volia k vlasti. Opyt pereotsenki vsekh tsennostei [The will to power. An attempted revaluation of all values], Kul'turnaia revoliutsiia Publ., Moscow, Russia

21. Ukhtomskii, A. A. (1997), Zasluzhennyi sobesednik: etika, religiia, nauka [The honoured interlocutor: ethics, religion, science], Rybinskoe podvor'e, Rybinsk, Russia.

22. Bakhtin, M. M. (2003), "K filosofii postupka" [To the philosophy of action], in Bakhtin, M. M. Sobranie sochinenii [Collected works], in 7 vols., vol. 1, Philosophical aesthetics of the 1920s, Russkie slovari, Iazyki slavianskoi kul'tury, Moscow, Russia.

23. Soboleva, M.E. (2012), “Bor”ba za istinnyi marksizm. Bogdanovskaia interpretatsiia monizma Spinozy" [The struggle for the true Marxism. Bogdanov's interpretation of Spinoza's monism], Veche. Zhurnal russkoi filosofi i kul'tury, vol. 24, pp. 137-147.

24. Marx, K. (1955), “Tezisy o Feierbakhe” [Theses on Feuerbach], in Marx, K. and Engels, F. Sochineniia [Works], vol. 3, Gosudarstvennoe izdatel'stvo politicheskoi literatury, Moscow, Russia.

25. Vvedenskii, A. I. (1892), O predelakh i priznakakh odushevleniia: Novyi psikhofizicheskii zakon v sviazi s voprosom o vozmozhnosti metafiziki [On the bounds and signs of animation: New psychophysical law in connection with the question of the possibility of metaphysics], Tipografiia V.S. Balasheva, St. Petersburg, Russia.

26. Vvedenskii, A. I. (1996), Stat'i po filosofii [Philosophy articles], Izdatel'stvo SPbGU, St. Petersburg, Russia.

27. Vernadskii, V.I. (1991), Nauchnaia mysl' kak planetnoe iavlenie [Scientific thought as a planetary phenomenon], Nauka, Moscow, Russia. 
28. Bogdanov, A.A. (1990), "Novyi mir" [The new world], in Bogdanov, A. A. Voprosy sotsializma: Raboty raznykh let [Problems of socialism: Works of different years], Politizdat, Moscow, Russia.

29. Bogdanov, A. A. (2010), Filosofiia zhivogo opyta: Materializm, empiriokrititsizm, dialekticheskii materializm, empiriomonizm, nauka budushchego. Populiarnyye ocherki [The philosophy of living experience: Materialism, empiriocriticism, dialectical materialism, empiriomonism, the science of the future. Popular essays], URSS Publ., Moscow, Russia.

30. Yushkevich, P.S. (2011), Mirovozzrenie i mirovozzreniia: Ocherki i kharakteristiki [Worldview and worldviews: Essays and characteristics], Librokom, Moscow, Russia.

Received: June 1, 2018

Accepted: October 3, 2018

Author's information:

Aleksandr E. Rybas — PhD, Associate Professor; a.rybas@spbu.ru

\section{Философия как деантропологизированное познание: идеи русского эмпириокритицизма}

\section{A. E. Pbбac}

Санкт-Петербургский государственный университет,

Российская Федерация, 199034, Санкт-Петербург, Университетская наб., 7-9

Для цитирования: Pыбас А.Е. Философия как деантропологизированное познание: идеи русского эмпириокритицизма // Вестник Санкт-Петербургского университета. Философия и конфликтология. 2019. Т. 35. Вып. 1. С. 107-118. https://doi.org/10.21638/spbu17.2019.109 (In English)

В статье анализируется проблемный подход к пониманию человека, который был характерен для русских эмпириокритиков рубежа XIX-XX вв. Показано, что этот подход предполагает возможность процессуального осмысления предметности философского познания, что, в свою очередь, требует критического преодоления метафизической рациональности. Проблематика русского позитивизма рассматривается посредством анализа двух основных "раздражителей» философской традиции: антиметафизического пафоса и новой модели познания. Метафизика как объект критики русских позитивистов представляла собой особую стратегию постижения абсолютной истины, или же такую систему знания, которая была основана на незнании, т. е. на целом ряде допущений, принятых на веру и исключающих возможность какой-либо проверки. Рассматриваются наиболее интересные попытки создания философии «неметафизического всеединства»: эмпириомонизм и тектология А. А. Богданова, научная философия В.В.Лесевича, эмпириосимволизм П.С.Юшкевича, философия жизни С.А.Суворова и позитивная эстетика А. В. Луначарского. Эти теории анализируются в контексте моделирования системы нового, неклассического, или же деантропологизированного философского познания. Суть деантропологизации сводится к устранению субъектобъектной диспозиции как исходной посылки философии и к рассмотрению субъективности как множества историко-культурных форм, сопряженных с соответствующими теоретико-метафизическими конструктами объективной реальности. При таком подходе человек утрачивает традиционно приписываемые ему субстанциальные характеристики и рассматривается исходя из его существования, а не сущности, а субъект-объектная диспозиция понимается как один из исторически обусловленных способов интерпретации сущего. Другими словами, человек осмысляется как «проблема», которая требует решения, но принципиально не может быть разрешена. Проблема человека раскрывается посредством деструкции и актуализации его основных исто- 
рических определенностей. Обосновывается положение русских позитивистов о том, что философия может существовать только в форме историко-философского дискур$\mathrm{ca}$, который ведется не с целью воссоздания существовавших философских учений, а с целью творческого моделирования возможной действительности.

Ключевые слова: русская философия, позитивизм, проблема человека, субъект, деструкция субъективности, собирание человека, деантропологизированное познание.

Статья поступила в редакцию 1 июня 2018 г.; рекомендована в печать 3 октября 2018 г.

Контактная информация:

Александр Е. Рьъбас — канд. филос. наук, доц.; a.rybas@spbu.ru 